NASA/CR-1998-208517

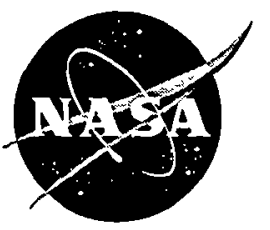

(1)

ARL-CR-430

NASA/CR-1998-208517

1998

19980237945

(1)

\title{
Evaluation of Navy 9 cst Oil in Bell Helicopter M412 HP Gearboxes
}

Zachary S. Henry and William R. Stapper

Bell Helicopter Textron, Inc., Fort Worth, Texas 
Since its founding, NASA has been dedicated to the advancement of aeronautics and space science. The NASA Scientific and Technical Information (STI) Program Office plays a key part in helping NASA maintain thus important role.

The NASA STI Program Office is operated by Langley Research Center, the Lead Center for NASA's scientific and technical information The NASA STI Program Office provides access to the NASA STI Database, the largest collection of aeronautical and space science STI in the world The Program Office is also NASA's institutional mechanism for disseminating the results of its research and development activities These results are published by NASA in the NASA STI Report Series, which includes the following report types:

- TECHNICAL PUBLICATION. Reports of completed research or a major signuficant phase of research that present the results of NASA programs and include extensive data or theoretical analysis Includes compilations of significant scientific and technical data and information deemed to be of continuing reference value. NASA's counterpart of peerreviewed formal professional papers but has less stringent limitations on manuscript length and extent of graphic presentations.

- TECHNICAL MEMORANDUM Scientfic and technical findings that are prelıminary or of specialized interest, e g., quick release reports, working papers, and bibliographies that contain munumal annotation. Does not contain extensive analysis.

- CONTRACTOR REPORT. Scientific and technical findings by NASA-sponsored contractors and grantees.
- CONFERENCE PUBLICATION. Collected papers from scientific and technical conferences, symposia, seminars, or other meetings sponsored or cosponsored by NASA.

- SPECIAL PUBLICATION Scientific, technical, or historical information from NASA programs, projects, and missions, often concerned with subjects having substantial public interest.

- TECHNICAL TRANSLATION. Englishlanguage translations of foreign scientific and technical material pertinent to NASA's mission

Specialized services that complement the STI Program Office's diverse offerings include creating custom thesaur, building customized data bases, organizıng and publıshing research results ...even providing videos

For more information about the NASA STI Program Office, see the following

- Access the NASA STI Program Home Page at http://www.sti.nasa.gov

- E-mail your question via the Internet to help@stı nasa.gov

- Fax your question to the NASA Access Help Desk at (301) 621-0134

- Telephone the NASA Access Help Desk at (301) 621-0390

- Write to: NASA Access Help Desk NASA Center for AeroSpace Information 7121 Standard Drive Hanover, MD 21076 
NASA/CR-1998-208517
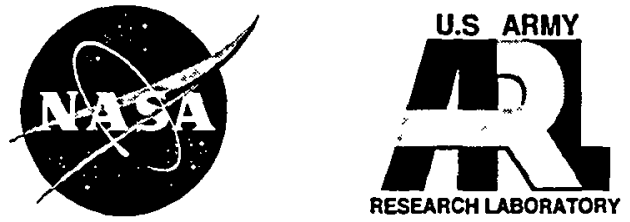

Evaluation of Navy 9 cst Oil in Bell Helicopter M412 HP Gearboxes

Zachary S. Henry and William R. Stapper

Bell Helicopter Textron, Inc., Fort Worth, Texas

Prepared under Contract NAS3-25455

National Aeronautics and

Space Administration

Lewis Research Center 
Trade names or manufacturers' names are used in this report for identification only This usage does not constitute an official endorsement, ether expressed or implied, by the National Aeronautics and Space Administration.

Avallable from

NASA Center for Aerospace Information

National Technical Information Service 7121 Standard Drive 5287 Port Royal Road

Hanover, MD 21076 Springfield, VA 22100

Price Code: A03 Price Code A03 


\begin{abstract}
Tests were conducted with 5 and 9 centistoke lubricants in three different helicopter gearboxes, a main transmission, a $42^{\circ}$ gearbox and a tailrotor gearbox. The objective of the tests was to observe and measure the difference in the performance of the lubrication systems due to the viscosity difference between the two test lubricants. The 9 centistoke oil has been developed to provide higher component film thickness, increased load carrying capacity and improved corrosion resistance which will provide increased life for drive system gears and bearings. The results of the tests showed that at stabilized operating speeds and powers, the lubrication system performance of the 3 gearboxes with the 9 centistoke lubricant was similar to the performance with the 5 centistoke lubricant. These results allow limited aircraft flight testing using the 9 centistoke lubricant in place of the 5 centistoke lubricant for aircraft with gearboxes similar to the test gearboxes.
\end{abstract}

\title{
Introduction
}

As part of the Navy optimum oil development program, the Naval Air Warfare Center, Aircraft Division, Trenton (NAWCADTRN) is directing the development and testing of a 9 centistoke (cst) helicopter transmission oil which is intended to replace 5 cst DOD-L-85734 oil. The 9 cst oil will provide higher component film thickness, increased load carrying capacity and improved corrosion resistance which will result in increased life for drive system gears and bearings. The 9 cst oil has been successfully evaluated in laboratory tests and simple mechanical rig tests. A comparison of the two oils is presented in Table I.

Additional full-scale helicopter transmission tests were conducted on the Model $412 \mathrm{HP}$ main transmission, $42^{\circ}$ gearbox and tailrotor gearbox. The purpose of these tests was to evaluate the effects on the gearbox lubrication systems when the standard 5 cst DOD-L-85734 oil was replaced with the $9 \mathrm{cst}$ developmental oil provided by NAWCADTRN. It was expected that the higher viscosity would significantly affect the lubrication system pressures, flow rates, and temperatures requiring some modification of the lube system or system operating parameters for acceptable operation with the 9 cst oil.

\section{Test Specimen}

The test gearboxes were a main transmission assembly, a $42^{\circ}$ gearbox assembly, and a tailrotor gearbox assembly. The $42^{\circ}$ and tailrotor gearboxes are not $412 \mathrm{HP}$ boxes but are similar to those installed in UH-1N helicopters. A cross-section of the main transmission is shown in Figure 1 and a schematic of the drive train is shown in Figure 2.

The following components of the test gearboxes were re-black oxided: (i) ring gear, (ii) upper planetary sun gear, (iii) lower planetary sun gear, (iv) input spiral bevel pinion, (v) input spiral bevel gear, (vi) upper and lower planet pinions (12 pcs), (vii) upper and lower planet bearing inner races (12 pcs), (vii) tailrotor spiral bevel pinion 
TABLE I. Comparison of Properties of 5 cst Oil with 9 cst Oil

\begin{tabular}{|c|c|c|c|c|}
\hline \multirow{2}{*}{ Lubricant Property } & \multicolumn{2}{|c|}{ DOD-L-85734 (5cst Oil) } & \multicolumn{2}{|c|}{9 cst Oil } \\
\hline & Requirement & Typical & Requirement & Actual \\
\hline Viscosity, cst & $23.0 \mathrm{~min}$ & 264 & report & 52.24 \\
\hline @ $100^{\circ} \mathrm{C}$ & 4.90 to 5.40 & 51 & 875 to 9.25 & 8.96 \\
\hline (a) $-40^{\circ} \mathrm{C}$ & 13,000 & 9,000 & $\mathbf{n} / \mathbf{a}$ & \\
\hline (a) $-25^{\circ} \mathrm{C}$ & $\mathrm{n} / \mathrm{a}$ & & 13,000 & 13,350 \\
\hline Pour Point, ${ }^{\circ} \mathrm{C} \mathrm{min}$ & -54 & -60 & -46 & -60 \\
\hline Flash Point, ${ }^{\circ} \mathrm{C}$ min & 246 & 254 & 246 & 288 \\
\hline Evaporation, \% (after $6.5 \mathrm{hr} @ 204^{\circ} \mathrm{C}$, max) & 10 & 1.8 & 5 & 3 \\
\hline Total Acid Number (mg/KOH/g, max) & 05 & 038 & 1 & 1 \\
\hline$\frac{\text { Oxidation and Corrosion Stab. @ } 150^{\circ} \mathrm{C}}{\text { Viscosity Change, \% }}$ & & & $15 \max$ & 41 \\
\hline TAN Change & & & $2.0 \max$ & 002 \\
\hline Metal Wt. Loss & & & pass & pass \\
\hline \begin{tabular}{|r|} 
Oxidation and Corrosion Stab.@ $175^{\circ} \mathrm{C}$ \\
Viscosity Change, \%
\end{tabular} & $15 \max$ & 10.3 & $25 \max$ & 81 \\
\hline TAN Change & $2.0 \max$ & 056 & $3.0 \max$ & 0.16 \\
\hline Metal Wt. Loss & pass & pass & pass & pass \\
\hline$\frac{\text { Oxidation and Corrosion Stab @204 }{ }^{\circ} \mathrm{C}}{\text { Viscosity Change, \% }}$ & $30 \max$ & 199 & report & 528 \\
\hline TAN Change & $3.0 \max$ & 077 & report & 43 \\
\hline Metal Wt. Loss & pass & pass & report & pass \\
\hline$\frac{\text { Oxidation and Corrosion Stab @, } 218^{\circ} \mathrm{C}}{\text { Viscosity Change, \% }}$ & report & 543 & & \\
\hline TAN Change & report & 67 & & \\
\hline Metal Wt. Loss & report & pass & & \\
\hline Ball Corrosion Test & $n / a$ & fail & pass & pass \\
\hline Ryder Gear Test \% ref. Oll, min & 145 & 160 & 200 & 205 \\
\hline
\end{tabular}

Prior to assembly of the gearboxes, a light coat of Permalon 327 was applied to both sides of the teeth in two equally spaced sets of approximately three gear teeth on the input spiral bevel pinion, input spiral bevel gear, tailrotor spiral bevel pinion, and two planet pinions, one for the upper planetary and one for the lower planetary.

Each gearbox was serviced with the 9 cst oil provided by NAWCADTRN, and a new 3 micron oil filter element was installed in the main transmission lube system. 


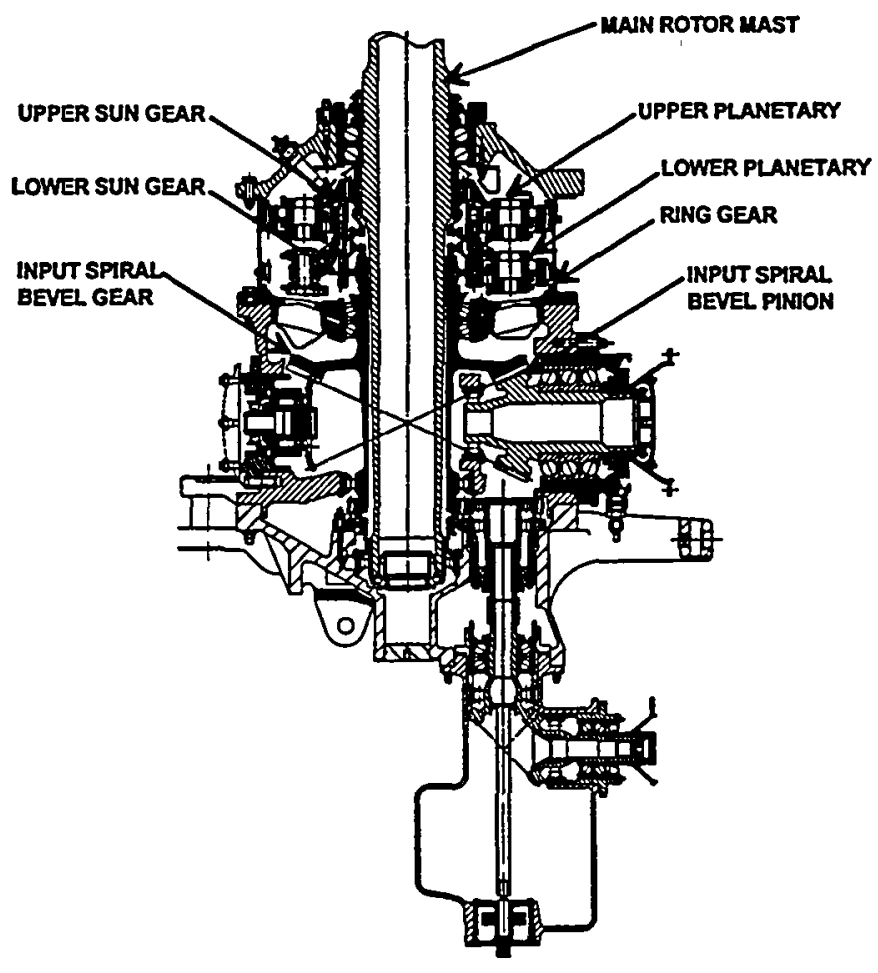

Figure 1. Cross-section of M412 Main Transmission

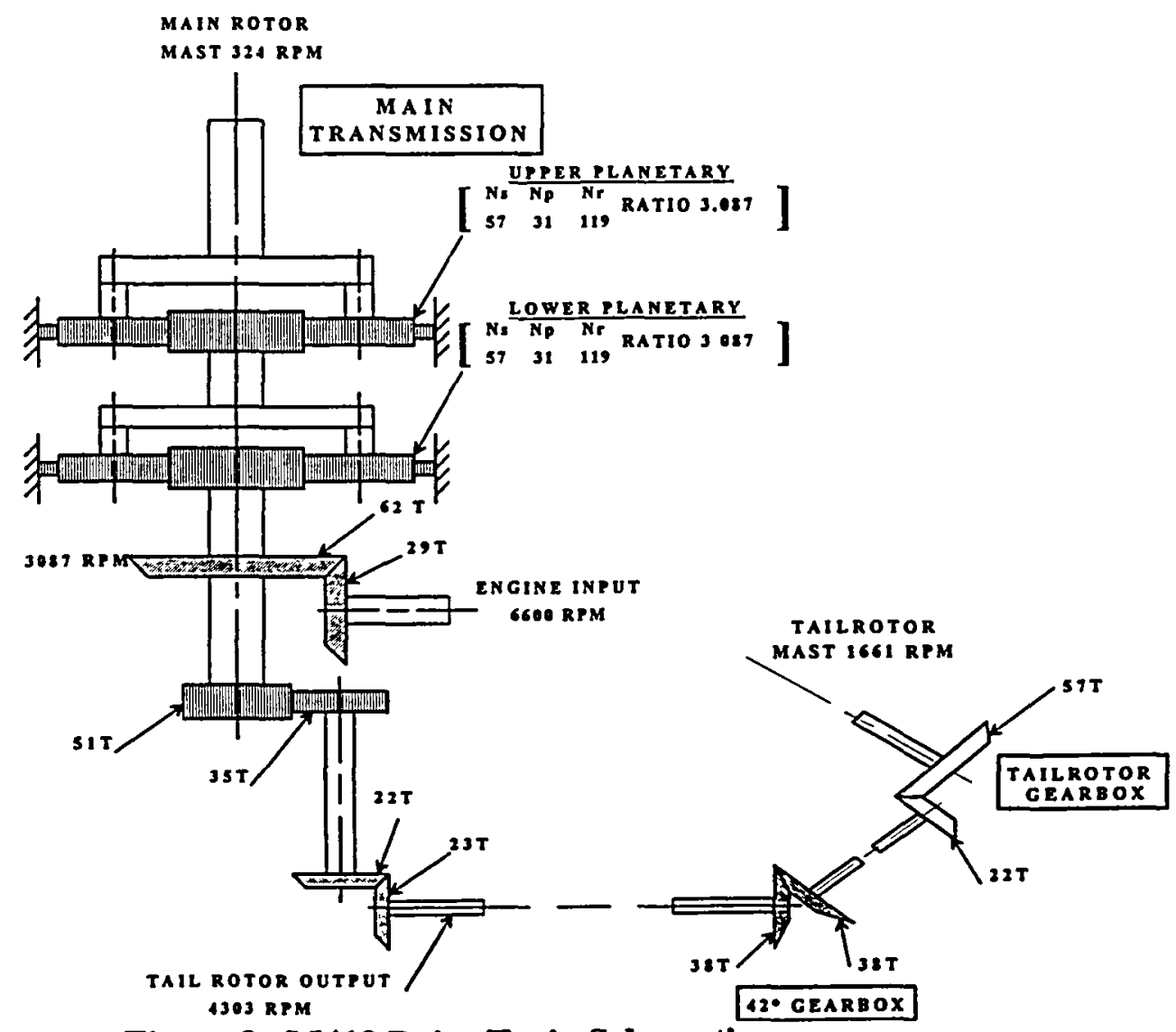

Figure 2. M412 Drive Train Schematic 


\section{Test Apparatus and Instrumentation}

The tests were conducted in an electrically driven, mechanically regenerative test stand. A schematic of the test stand is shown in Figure 3. This stand is capable of loading the main rotor mast and the tailrotor gearbox output shaft simultaneously. The mast assembly was instrumented to measure the output torque.

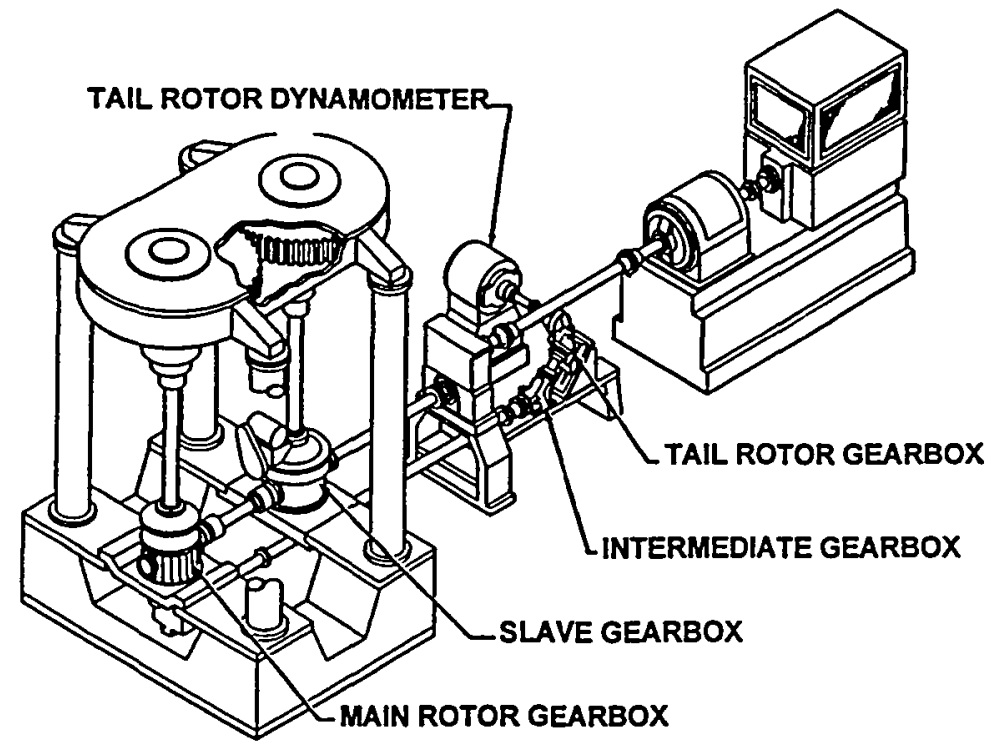

Figure 3. Regenerative Test Stand

The following test conditions were measured and recorded at 10 second intervals during all testing:

Time of day

Total test time

Test cell ambient temperature 2-4 ft from transmission

Main Transmission input rpm

Main Transmission oil-in temperature

Main Transmission oil-out temperature

Main rotor mast torque

Main Transmission input triplex bearing outer race temperatures ( 3 places - see Figure 4)

Main Transmission oil pump outlet pressure

Main Transmission regulated oil pressure

Main Transmission mast oil jet pressure

Main Transmission oil filter differential pressure

Main Transmission heat exchanger cooling water flow rate

Main Transmission heat exchanger cooling water-in temperature

Main Transmission heat exchanger cooling water-out temperature

Tail Rotor gearbox output shaft torque

Tail Rotor gearbox sump oil temperature

$42^{\circ}$ gearbox sump oil temperature 

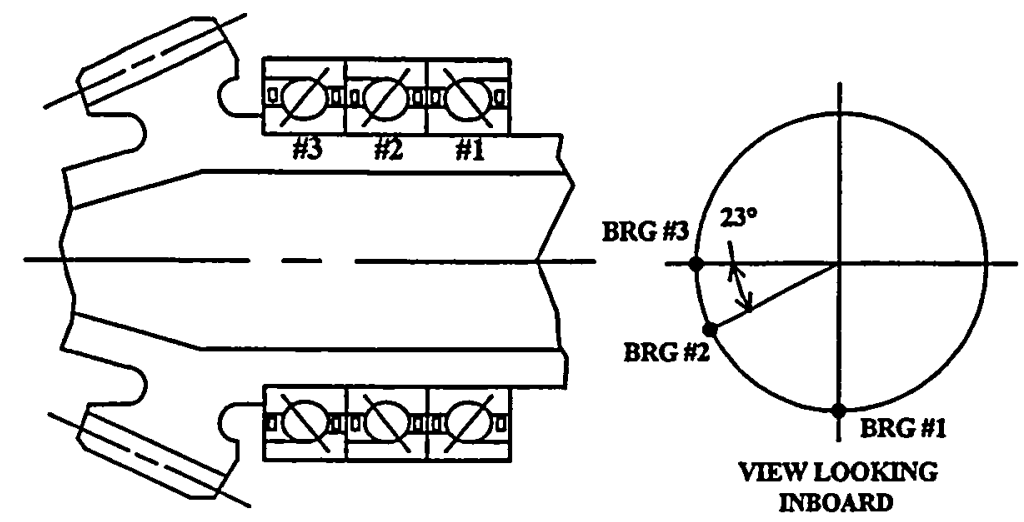

Figure 4. Schematic - Input Triplex Bearing Outer Race Thermocouple Locations

\section{Test Specimen Green-Run Procedure}

The main transmission, $42^{\circ}$ gearbox, and tailrotor gearboxes were green-run to the loads and speeds specified in Table II. The main transmission oil inlet pressure was set at $55 \pm 3$ psi with the oil inlet temperature at $200^{\circ} \pm 10^{\circ} \mathrm{F}$ while operating at $6600 \mathrm{rpm}$ input speed during Step 4 .

\section{TABLE II: 1.0 Hour Green-run Schedule}

\begin{tabular}{|c|c|c|c|c|c|c|}
\hline STEP NO. & $\begin{array}{c}\text { INPUT } \\
\text { RPM }\end{array}$ & $\begin{array}{c}\text { MAST } \\
\text { TORQUE } \\
\text { (IN-LBS) }\end{array}$ & $\begin{array}{c}\text { MAST HP } \\
\text { (REF) }\end{array}$ & $\begin{array}{c}\text { TAILROTOR GBOX } \\
\text { OUTPUT SHAFT } \\
\text { TORQUE (IN-LBS) }\end{array}$ & $\begin{array}{c}\text { TAIL ROTOR } \\
\text { HP (REF) }\end{array}$ & $\begin{array}{c}\text { RUN TIME } \\
\text { (MIN) }\end{array}$ \\
\hline \hline 1 & 4,000 & Min. & Min. & Min. & Min. & 6 \\
\hline 2 & 5,000 & 25,000 & 97 & 1,000 & 20 & 6 \\
\hline 3 & 6,000 & 50,000 & 234 & 2,000 & 48 & 6 \\
\hline 4 & 6,600 & 75,000 & 386 & 2,500 & 66 & 6 \\
\hline 5 & 6,600 & 100,000 & 514 & 3,500 & 92 & 6 \\
\hline 6 & 6,600 & 140,000 & 720 & 4,000 & 105 & 6 \\
\hline 7 & 6,600 & 180,000 & 925 & 5,000 & 132 & 6 \\
\hline 8 & 6,600 & 220,000 & 1,131 & 6,000 & 158 & 6 \\
\hline 9 & 6,600 & 265,000 & 1,362 & 6,830 & 180 & 6 \\
\hline 10 & 7,040 & 159,000 & 872 & 2,300 & 65 & 6 \\
\hline
\end{tabular}

Notes:

1. For steps 1 thru 9 , the speed was set first, then the torque was increased to the required levels.

2. For step 10 the torque was reduced to the required levels, then the speed increased to $7,040 \mathrm{rpm}$. 
After the green-run was completed, the gearboxes were inspected for any visible oil leaks and the chip detectors for debris. The lubricating jets were also visually inspected for foreign material, burrs, or other damage.

Immediately after the completion of Step 10, the gearboxes were shut down and a 6 ounce oil sample was collected from each gearbox for analysis. The oil was collected through a clean drain valve to prevent contamination. The oil was drained from each gearbox and the test stand lube system and was replaced with new 9 cst oil.

\section{Cst Oil Evaluation Test Procedure}

With the oil inlet pressure set at $55 \pm 3$ psi when the oil inlet temperature was $200^{\circ} \pm 10^{\circ} \mathrm{F}$, the load and speed conditions shown in Table III for the main transmission and tailrotor gearboxes were repeated eight times for a total run time of 48 hours.

TABLE III: 9 cst Oil - 6 Hour Evaluation Run Schedule (Repeat 8 times for 48 hr total)

\begin{tabular}{|c|c|c|c|c|c|c|}
\hline STEP NO. & INPUT RPM & $\begin{array}{c}\text { MAST } \\
\text { TORQUE } \\
\text { (IN-LBS) }\end{array}$ & $\begin{array}{c}\text { MAST HP } \\
\text { (REF) }\end{array}$ & $\begin{array}{c}\text { TAILROTOR GBOX } \\
\text { OUTPUT SHAFT } \\
\text { TORQUE (IN-LBS) }\end{array}$ & $\begin{array}{c}\text { TAIL ROTOR } \\
\text { HP (REF) }\end{array}$ & $\begin{array}{c}\text { RUN TIME } \\
\text { (HOUR) }\end{array}$ \\
\hline \hline 1 & 6,600 & Min & Min & Min & Min & 0.5 \\
\hline 2 & 6,600 & 100,000 & 514 & 2,000 & 53 & 1 \\
\hline 3 & 6,600 & 200,000 & 1,028 & 4,500 & 119 & 1 \\
\hline 4 & 6,600 & 265,000 & 1,362 & 6,830 & 180 & 2 \\
\hline 5 & 7,040 & 159,000 & 872 & 2,300 & 65 & 1 \\
\hline 6 & 7,040 & Min & Min & Min & Min & 0.5 \\
\hline
\end{tabular}

Notes:

1. For steps 1 thru 4 , the speed was set first, then the torque was increased to the required levels.

2. For step 5 the torque was reduced to the required levels, then the speed increased to $7,040 \mathrm{rpm}$.

Immediately after completing the 48 hour test, the gearboxes were shut down and a 6 ounce oil sample was collected from each gearbox for analysis. The oil was collected through a clean drain valve to prevent contamination.

The main transmission was partially disassembled to photograph the gear tooth contact patterns on one upper planetary pinion and on the input spiral bevel pinion. One upper planet pinion was removed and disassembled to photograph the inner race roller load zone. The tailrotor gearbox was partially disassembled to photograph the contact pattern on the input spiral bevel pinion. 
The gearboxes were reassembled, and the oil drained from each gearbox (main transmission, $42^{\circ}$ gearbox, and tailrotor gearbox) and the test stand lube system, and replaced with $5 \mathrm{cst}$ oil per DOD-L-85734. The main transmission oil filter was not replaced at this time.

After reservicing the gearboxes with the $5 \mathrm{cst}$ oil, the 1.0 hour green-run and post green-run inspection were repeated. Before resetting the oil pressure regulator (the setting from the $9 \mathrm{cst}$ oil test was maintained) to the specified green-run requirements, the oil pressure during Step 4 was measured and recorded when the oil inlet temperature was at $200^{\circ} \pm 10^{\circ} \mathrm{F}$. The oil was drained from each gearbox (main transmission, $42^{\circ}$ gearbox, and tailrotor gearbox) and the test stand lube system, and replaced with new 5 cst oil per DOD-L-85734. The main transmission oil filter was also replaced at this time.

\section{Cst (DOD-L-85734) Baseline Oil Evaluation Test Procedure}

With the oil inlet pressure set at $55 \pm 3$ psi when the oil inlet temperature was $200^{\circ} \pm 10^{\circ} \mathrm{F}$, the main transmission and tailrotor gearboxes were run at the load and speed conditions shown in Table IV for a total run time of 5 hours.

TABLE IV: Baseline 5 cst Oil - 5 Hour Evaluation Run Schedule

\begin{tabular}{|c|c|c|c|c|c|c|}
\hline STEP NO. & INPUT RPM & $\begin{array}{c}\text { MAST } \\
\text { TORQUE } \\
\text { (IN-LBS) }\end{array}$ & $\begin{array}{c}\text { MAST HPP } \\
\text { (REF) }\end{array}$ & $\begin{array}{c}\text { TAILROTOR GBOX } \\
\text { OUTPUT SHAFT } \\
\text { TORQUE (IN-LBS) }\end{array}$ & $\begin{array}{c}\text { TAIL ROTOR } \\
\text { HP (REF) }\end{array}$ & $\begin{array}{c}\text { RUN TIME } \\
\text { (HOUR) }\end{array}$ \\
\hline \hline 1 & 6,600 & Min & Min & Min & Min & 0.5 \\
\hline 2 & 6,600 & 100,000 & 514 & 2,000 & 53 & 1 \\
\hline 3 & 6,600 & 200,000 & 1,028 & 4,500 & 119 & 1 \\
\hline 4 & 6,600 & 265,000 & 1,362 & 6,830 & 180 & 1 \\
\hline 5 & 7,040 & 159,000 & 872 & 2,300 & 65 & 1 \\
\hline 6 & 7,040 & Min & Min & Min & Min & 0.5 \\
\hline
\end{tabular}

Notes:

1. For steps 1 thru 4 , the speed was set first, then the torque was increased to the required levels.

2. For step 5 the torque was reduced to the required levels, then the speed increased to $7,040 \mathrm{rpm}$.

Immediately after completion of the 5 hour test, the gearboxes were shut down and a 6 ounce oil sample was collected from each gearbox for analysis. The oil was collected through a clean drain valve to prevent contamination.

The main transmission was partially disassembled to re-photograph the gear tooth contact patterns on one upper planetary pinion, the input spiral bevel pinion and the inner race roller load 
zone photographed after the 48 hour run. The tailrotor gearbox was partially disassembled to re-photograph the contact pattern on the input spiral bevel pinion.

\section{Test Results}

After completing the 48 hour test with the $9 \mathrm{cst}$ oil, the gearboxes were partially disassembled for visual inspection. No contact patterns were readily visible on the gear teeth, and none of the gearbox components exhibited any signs of wear or distress. Each gearbox was reassembled and the 5 hour test with 5 cst DOD-L-85734 oil was conducted using the same 6 load steps used to accumulate the 48 hour run time with the 9 cst oil. After the 5 hour test, the gearboxes were again partially disassembled for inspection. Again, no contact patterns were readily visible on the gear teeth, and none of the gearbox components exhibited any signs of wear or distress.

A comparison of the results of running at each of the test steps with the 9 cst and 5 cst oils is shown in Figures 5 through 7 for selected temperatures of each gearbox. While there are some differences in temperatures for the two oils, the differences are minimal during the maximum torque run (step 4) when the maximum temperatures are generated. The most pronounced differences in temperatures occur when the gearboxes were run at overspeed conditions with minimal torque (step 7) where the 9 cst oil produced higher temperatures as a result of increased viscosity. It should be noted that the test drive system is a relatively low speed system (maximum component speed $6600 \mathrm{rpm}$ ) where heat generation may be dominated by frictional losses; whereas a high speed system with maximum component speeds greater than $15,000 \mathrm{rpm}$ would more likely show heat generation to be dominated by viscous losses. During step 3 of the 5 cst oil test, a test stand cooling fan directed at the $42^{\circ}$ and $90^{\circ}$ gearboxes was inadvertently turned off resulting in the high bulk oil temperatures shown in Figures 6 and 7.

The following observations were also made comparing the test results of the two oils (See Table V):

1. No change was required in the oil pressure regulator setting when the 9 cst oil was replaced with the $5 \mathrm{cst}$ oil in the main transmission.

2. The oil pressure drop across the filter assembly shown in Figure 8 was only slightly higher for the 9 cst oil with the most pronounced difference at the overspeed conditions of steps 5 and 6 .

3. The difference between the oil-in temperature and the main transmission input triplex bearing (see Figure 4 for location) temperature was slightly higher for the 9 cst oil.

4. There was no significant difference in the oil pump outlet pressure for the two oils.

5. For each of the oils tested, there was no difference in the oil pressure measured at the mast jet. This jet is located furthest from the oil pump. 
6. Cooling water flow rates and temperatures could not be accurately measured due to the low cooling water flow rate required to maintain the main transmission oil-in temperature at $200^{\circ} \mathrm{F}$.

NOTE: These comparisons were made at a stabilized oil-in temperature of $200^{\circ} \mathrm{F}$ and would be expected to be much different at lower operating temperatures.

Table V. Test Data

\begin{tabular}{|c|c|c|c|c|c|c|c|c|c|c|c|c|c|}
\hline \multirow{2}{*}{\multicolumn{2}{|c|}{ PARAMETERS }} & \multicolumn{6}{|c|}{ Test Steps ( 5 cst Oil) } & \multicolumn{6}{|c|}{ Test Steps ( 9 cst Oil) } \\
\hline & & 1 & 2 & 3 & 4 & 5 & 6 & 1 & 2 & 3 & 4 & 5 & \\
\hline & OIL-IN T & 200 & 193 & 204 & 198 & 196 & 200 & 193 & 200 & 205 & 200 & 202 & 201 \\
\hline & OII-OUT TEMP. $\left({ }^{\circ} \mathrm{F}\right)$ & 203 & 199 & 214 & 212 & 203 & \begin{tabular}{|l|}
203 \\
\end{tabular} & 199 & \begin{tabular}{|l|}
206 \\
\end{tabular} & 216 & 213 & 210 & $\overline{205}$ \\
\hline $\mathbf{N}$ & {$[($ OIL-IN) - (OIL-OUT)] } & 3 & $\overline{6}$ & 10 & 14 & 7 & 3 & 6 & $\overline{6}$ & 11 & 13 & 8 & 4 \\
\hline & MAX TRIPLEX TEMI & 220 & 217 & 234 & 235 & 226 & \begin{tabular}{|l|}
221 \\
\end{tabular} & 222 & 228 & 238 & 238 & 234 & 229 \\
\hline $\mathbf{X}$ & [OIL-IN - TRIPLEX B & $\overline{20}$ & 24 & 30 & 37 & 30 & 21 & 29 & 28 & 33 & 38 & 32 & 28 \\
\hline $\mathbf{S}$ & OIL PRESS. (PSI) & 56 & 56 & 56 & 56 & 58 & 58 & 56 & 56 & 55 & 56 & 57 & 57 \\
\hline $\mathbf{N}$ & PUMP OIL PRESS. (PSI) & 81 & 82 & 80 & 81 & 85 & 85 & 82 & 80 & 79 & 81 & 83 & 84 \\
\hline & MAST JET PRESS. (PSI) & 38 & 39 & 38 & 38 & 40 & $\overline{40}$ & 39 & 39 & 38 & 40 & 39 & 39 \\
\hline & FILTER $\triangle \mathrm{P}$ ( 3 micron filter) & 4 & 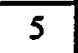 & 3 & 5 & J & 5 & 5 & 5 & $\overline{6}$ & 6 & $\begin{array}{l}7 \\
\end{array}$ & 8 \\
\hline & GBOX BULK 1 & 138 & 175 & 208 & 189 & 144 & \begin{tabular}{|l|}
131 \\
\end{tabular} & 149 & 157 & 179 & 192 & 160 & 160 \\
\hline & GBOX BULK TEMP. $\left({ }^{\circ} \mathrm{F}\right)$ & 144 & 164 & 186 & $\overline{180}$ & 150 & \begin{tabular}{|l|}
143 \\
\end{tabular} & \begin{tabular}{|l|}
157 \\
\end{tabular} & 156 & 174 & 188 & 170 & 169 \\
\hline
\end{tabular}




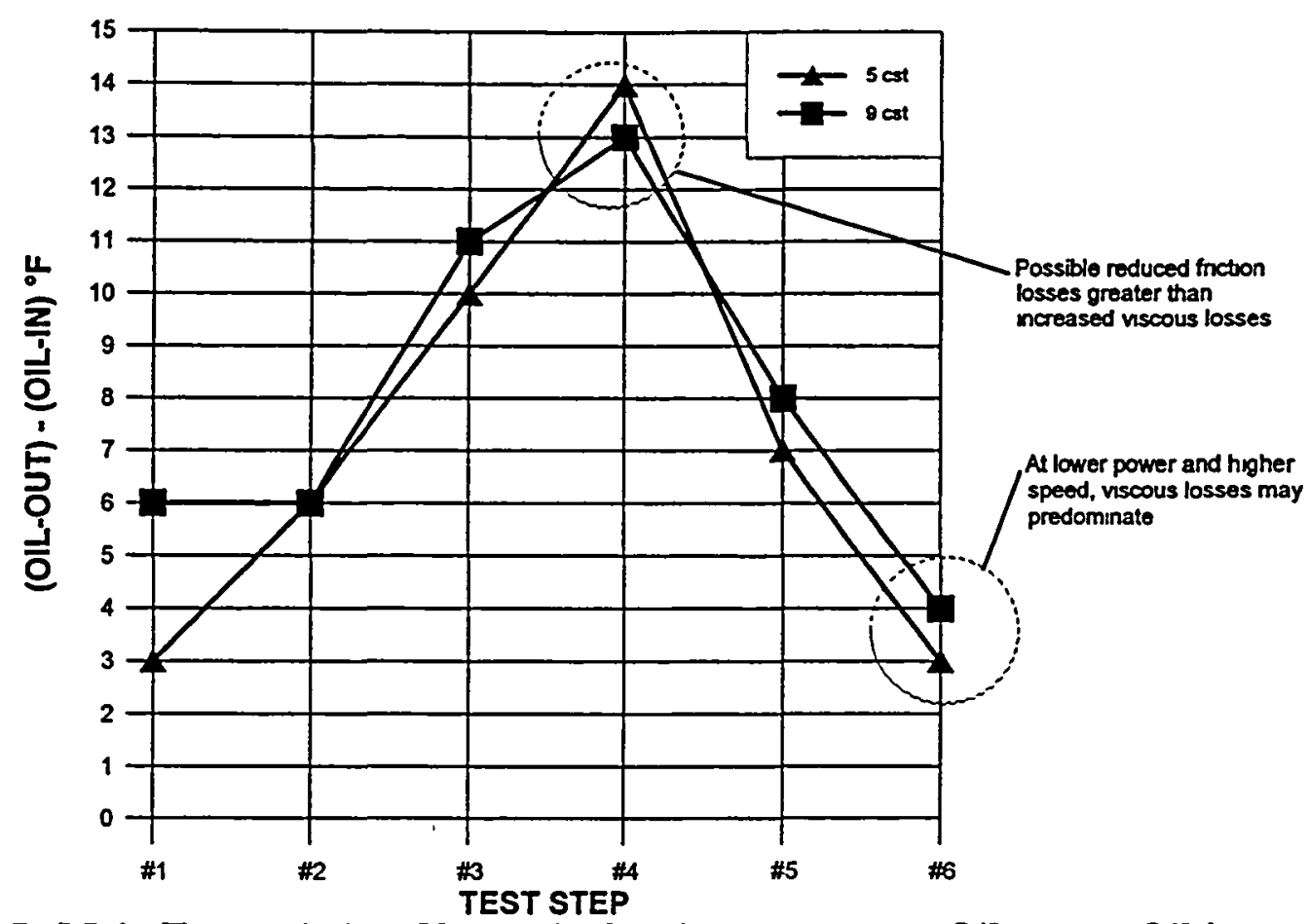

Figure 5. Main Transmission Change in Oil Temperature - Oil-out vs. Oil-in.

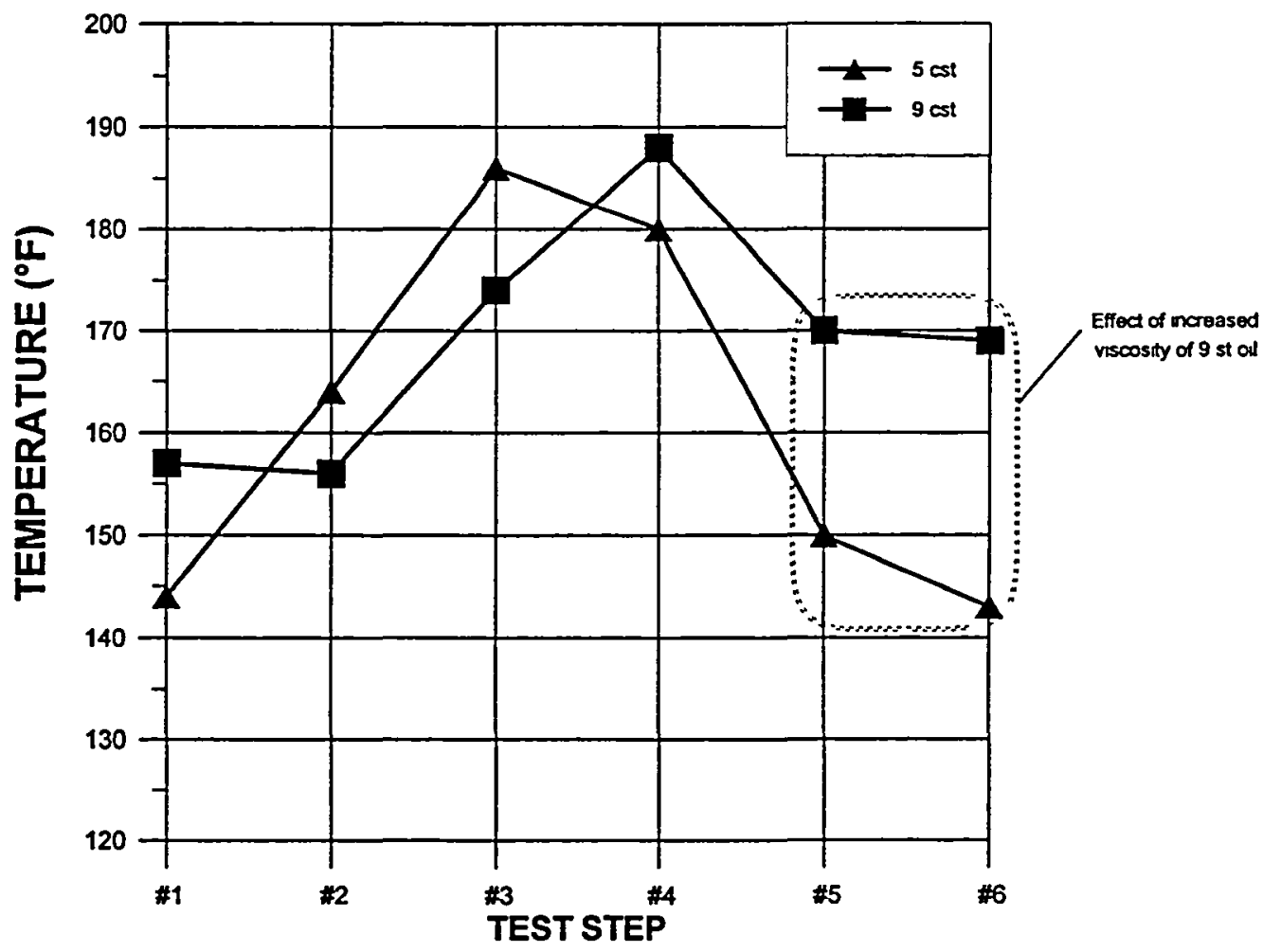

Figure 6. $42^{\circ}$ Gearbox Bulk Oil Temperature. 


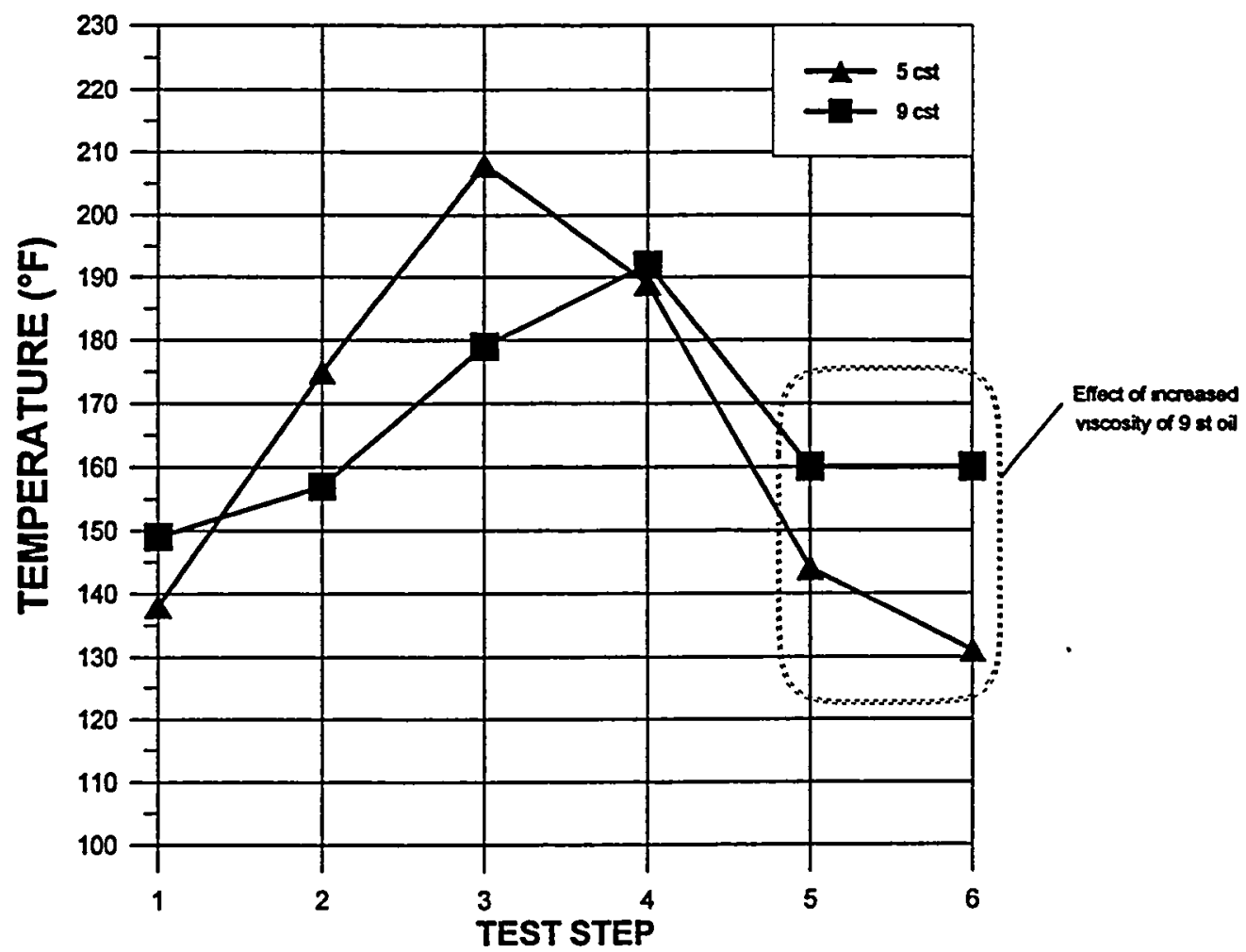

Figure 7. $90^{\circ}$ Gearbox Bulk Oil Temperature.

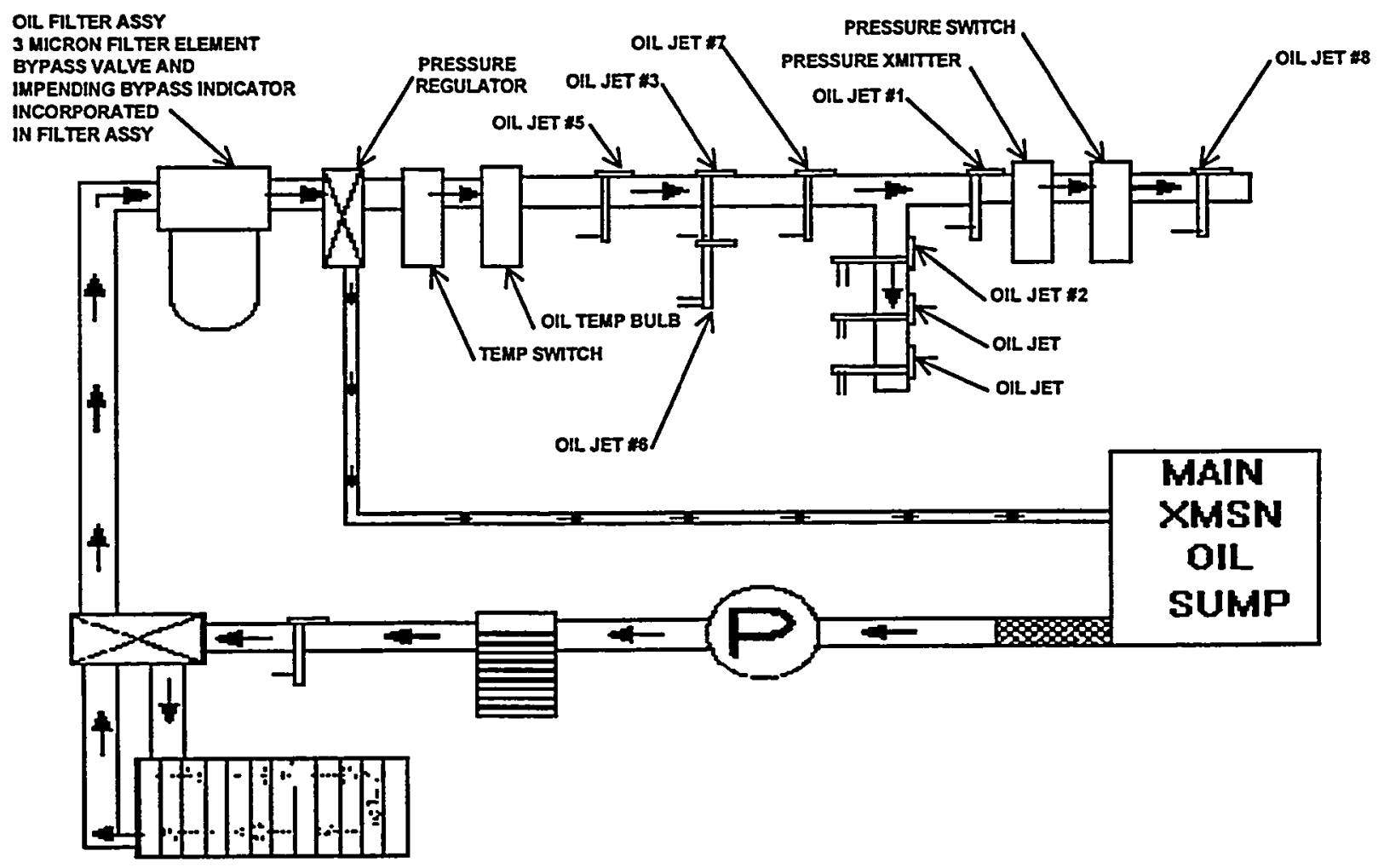

Figure 8. Lube System Schematic of Main Test Transmission . 


\section{$\underline{\text { Recommendations }}$}

Based on the results of the tests conducted on the M412 HP gearboxes, limited flight tests with 9 cst oil are acceptable. However, the following concerns should be properly addressed prior to any flight tests. The corrective actions noted are not required for flight tests if extreme ambient temperature conditions are avoided.

The increased kinematic viscosity of the 9 cst helicopter transmission oil will present a number of problems and potential problems to the operation of drive system lubrication systems of helicopters now in service. These problems and potential problems are discussed below.

\section{A. Definite Problems}

Data on a prototype $9 \mathrm{cst}$ (Nom, Std Grade) helicopter transmission oil indicates a kinematic viscosity ratio of approximately 1.71 at $212^{\circ} \mathrm{F}$ and 3.81 at $-25^{\circ} \mathrm{F}$ when compared to some oils conforming to DOD-L-85734. Since the specific gravity of the new 9 cst oil is quite similar to that of DOD-L-85734 oil, absolute viscosity ratios should approximate those for kinematic viscosity.

\section{Oil Filter Bypass Valves \& Oil Filter Impending Bypass Indicators}

Bypass valves and impending bypass indicators in the micronic transmission oil filter assemblies of older aircraft were sized based upon the pressure drop characteristics of the filters with MIL-L-7808 oil. The valves crack early as the filters load up and the impending bypass indicators often pop prematurely at lower ambient temperatures when MIL-L-23699 or DOD-L-85734 oils are used.

If the new 9 cst oil is used, pressure drops through the filters could increase to approximately $170 \%$ of the MIL-L-23699 pressure delta $(\Delta \mathrm{P})$. As a result, the filters will likely be bypassing oil well into the normal operating temperature range even with relatively clean filter elements.

The bypass valves and impending bypass indicators on later helicopters were sized based on filter performance with MIL-L-23699 oil. Premature bypass indications and very short filter lives (time to rated $\Delta P$ ) should be anticipated when using the $9 \mathrm{cst}$ oil.

During the tests conducted on the main transmission, no bypass was indicated, and the pressure differences across the oil filter were not very different for the two oils . However, additional evaluation is recommended since the absolute viscosity of the $9 \mathrm{cst}$ oil is approximately 1.8 times that of the $5 \mathrm{cst}$ oil at $200^{\circ} \mathrm{F}$. This viscosity difference should have caused the pressure drop across the oil filter for the 9 cst oil to be 1.8 times that of the 5 cst oil. The measured difference ranged from 0 to $3 \mathrm{psi}$. Failure to measure a 1.8 times increase in the pressure drop for the 9 cst oil may have been the result of the tolerance in the accuracy of the pressure transducers which can be as high as $\pm 1.5 \mathrm{psi}$. 


\section{CORRECTIVE ACTION:}

Redesign oil filter bypass valves and impending bypass indicators to actuate at $\Delta \mathrm{P}$ levels consistent with filter performance with 9 cst oil.

\section{Integral Full Flow Transmission Filter Screen}

This full-flow 80 micron screen filters the transmission oil before it leaves the transmission en-route to the oil coolers. The screen-filter has a bypass valve but no impending bypass indicator. Bypass valve problems and corrective actions are similar to those stated above for the micronic oil filters.

\section{Oil Cooler Circuit Bypass Valve}

(This component was not installed in the test transmission.)

This transmission mounted valve compares the flow rate of oil leaving the transmission for the oil cooler circuit to that of the oil returning from the circuit. Should a flow rate differential in excess of the valve's calibration point exist, the valve shifts, isolating the cooler circuit and routing the oil directly from the oil pump to the transmission. The valve was calibrated using MIL-L-23699 oil. Using the 9 cst oil instead of MIL-L-23699 oil, will increase the oil pressure drop through the oil cooler circuit which would cause the valve to shift under normal operating conditions. This will result in an abnormally high transmission oil temperature.

\section{CORRECTIVE ACTION:}

Modify the oil cooler circuit bypass valve and valve calibration procedures to be consistent with the aircraft oil cooler circuit pressure distribution when using 9 cst oil.

4. Transmission Oil Overpressure Relief Valve (This component was not installed in the test transmission.)

The transmission lubrication system on certain aircraft have an overpressure relief valve located in the transmission sump case near the oil pump discharge port. This valve is designed to limit oil pump discharge pressure to approximately $200 \mathrm{psi}$ during aircraft cold starts for aircraft using MIL-L-23699 oil. Using the higher viscosity 9 cst oil will increase oil pressure drops through out the transmission lubrication system. The higher pressure drops may cause the relief valve to dump oil for longer warm-up periods than was originally intended and/or to continue to dump oil in cases where filters are loaded near their dirt holding capacity.

\section{CORRECTIVE ACTION:}

Redesign the overpressure relief valve to open at a pressure consistent with the lubrication system pressure drop characteristics of 9 cst oil. 


\section{Gearbox Overheating}

The increased viscosity will increase the heat generated via viscous drag within certain gearboxes. The increased heat generation is expected to be minimal in main transmissions. Increased viscous losses may be significant in the tailrotor drive and intermediate gearboxes ( $42^{\circ}$ gearboxes) and will likely be a problem in the high speed combining gearbox found on some aircraft.

\section{CORRECTIVE ACTION:}

Bench and/or aircraft tests should be conducted to accurately determine the cooling margins (corrected to $125^{\circ} \mathrm{F}$ sea level standard conditions) for each gearbox when using 9 cst oil. The means of obtaining increased oil cooling would have to be determined for each gearbox.

\section{B. Potential Problems}

\section{Oil Cooler Thermostatic Valves}

\section{(This component was not installed in the test transmission)}

In general, the thermostatic valves in aircraft transmission oil coolers and in combining gearbox oil coolers are designed to fully close at approximately $160^{\circ} \mathrm{F}$, routing all oil through the heat exchanger. The valves also have a pressure relief function and will route a portion of oil around the heat exchanger when the oil pressure drop across the core exceeds 40 psi.

The construction of the plate-fin heat exchangers on the oil sides has long narrow oil passages designed to promote turbulent flow for increased heat transfer from the oil. Oil pressure drops through these passages is dependent upon the viscosity of the oil. Use of the new 9 cst oil can be expected to increase the pressure drop across the heat exchanger cores, and should the pressure drop exceed the cracking pressure of the thermostatic valve at any oil temperature at which the valve is seated, there will be reduced oil cooler performance.

\section{CORRECTIVE ACTION:}

Original oil cooler qualification data should be reviewed or bench tests conducted to determine the impact of the increased oil viscosity on the oil cooler pressure drop. If necessary, new thermostatic valves should be designed with appropriately increased cracking pressures.

\section{Reduced Oil Flows Within Gearboxes}

The lengths of oil jet metering orifices within the main transmissions, combining gearboxes, intermediate gearboxes and tail rotor gearboxes are such that the oil flow rates are not affected by relatively small changes in oil viscosity. There are however, small 
passages through which oil to some gearbox bearings is routed. With the 9 cst oil, there is a potential for reduced oil flow to those gearbox bearings at any given operating temperature.

\section{CORRECTIVE ACTION:}

This potential problem is expected to have minor impact on the gearbox performance. Slightly reduced oil flow to some bearings may actually reduce bearing operating temperatures.

Some gearbox bench tests should be conducted to determine the effect of the 9 cst oil on temperatures of suspect bearings. If the measured temperatures are excessive, oil flow rates would have to be increased by increasing gearbox oil pressure or increasing the oil passage size.

\section{Lubrication System Structural Integrity}

The transmission lubrication systems of some aircraft are not equipped with overpressure relief valves. In the past when using MIL-L-23699, high cold-start pump discharge pressures have required redesign of the seal on the transmission integral full-flow filter screen (change from compression gasket to o-ring seal). Higher lubrication system pressure drops associated with the use of 9 cst oil may result in pump discharge cold-start pressures that could cause structural damage to lubrication system components.

\section{CORRECTIVE ACTION:}

a. Limit use of the 9 cst oil to ambient temperatures above $-20^{\circ} \mathrm{F}$.

b. Redesign the transmission sump case to incorporate an overpressure relief valve.

\section{Conclusions}

Based on the results of these tests, the 9 cst oil can be used in place of the 5 cst oil in the gearboxes tested for ambient temperatures in excess of $70^{\circ} \mathrm{F}$.

No significant differences in the gearbox lubrication pressures or operating temperatures were observed between the $9 \mathrm{cst}$ and $5 \mathrm{cst}$ lubricants during the tests conducted at normal operating conditions of speed and torque. However, additional tests at both low starting ambient temperatures and high operating ambient temperatures should be conducted to determine the full range of differences between the two lubricants and their effects on the operation of the subject gearboxes. 
Public reporting burcten for this collection of information is estimated to average 1 hour per response, including the time for reviewing instructions searching existing data sources gathering and maintaining the data needed and completing and reviewing the collection of mformation Send comments regarding this burden estirnate or any other aspect of this Hearters Services, Directorate for Information Opera Davis Highway, Sute 1204, Artington, VA 22202-4302, and to the Office of Management and Budget, Paperwork Reduction Project (0704-0188) Washington, DC 20503

\begin{tabular}{|l|c|c|c} 
1. AGENCY USE ONLY (Leave blank) & $\begin{array}{c}2 \\
\text { REPORT DATE } \\
\text { August } 1998\end{array}$ & $\begin{array}{r}\text { REPORT TYPE AND DATES COVERED } \\
\text { Final Contractor Report }\end{array}$ \\
\hline
\end{tabular}

4 TITLE AND SUBTITLE 5. FUNDING NUMBERS

Evaluation of Navy 9 cst Oll in Bell Helıcopter M412 HP Gearboxes 6. AUTHOR(S)

Zachary S Henry and Willaam R Stapper

WU-581-30-13-00

NAS3-25455

1L162211A47A

7 PERFORMING ORGANIZATION NAME(S) AND ADDRESS(ES)

8 PERFORMING ORGANIZATION REPORT NUMBER

Bell Helicopter Textron, Inc

PO Box 482

E-11296

Fort Worth, Texas 76101

9. SPONSORING/MONITORING AGENCY NAME(S) AND ADDRESS(ES)

U S Army Research Laboratory

Cleveland, Ohio 44135-3191

and

NASA Lewis Research Center

Cleveland, Oho 44135-3191

10. SPONSORING/MONITORING AGENCY REPORT NUMBER

NASA CR-1998-208517

ARL-CR-430

11. SUPPLEMENTARY NOTES

Project Manager, Robert F Handschuh, U S Army Research Laboratory, NASA Lewis Research Center, organızation code 0300, (216) 433-3969

12a DISTRIBUTION/AVAILABILITY STATEMENT 12b. DISTRIBUTION CODE

Unclassified - Unlimited

Subject Category 37

Distribution Nonstandard

This publication is avallable from the NASA Center for AeroSpace Information, (301) 621-0390

13. ABSTRACT (Maximum 200 words)

Tests were conducted with 5 and 9 centistoke lubricants in three different helicopter gearboxes, a main transmission, a $42^{\circ}$ gearbox and a tailrotor gearbox The objective of the tests was to observe and measure the difference in the performance of the lubrication systems due to the viscosity difference between the two test lubricants The 9 centistoke oil has been developed to provide higher component film thickness, increased load carrying capacity and improved corrosion resistance which will provide increased life for drive system gears and bearings The results of the tests showed that at stabalized operating speeds and powers, the lubrication system performance of the 3 gearboxes with the 9 centistoke lubricant was similar to the performance with the 5 centistoke lubricant These results allow limited aircraft flight testıng using the 9 centistoke lubricant in place of the 5 centistoke lubricant for aircraft with gearboxes similar to the test gearboxes.

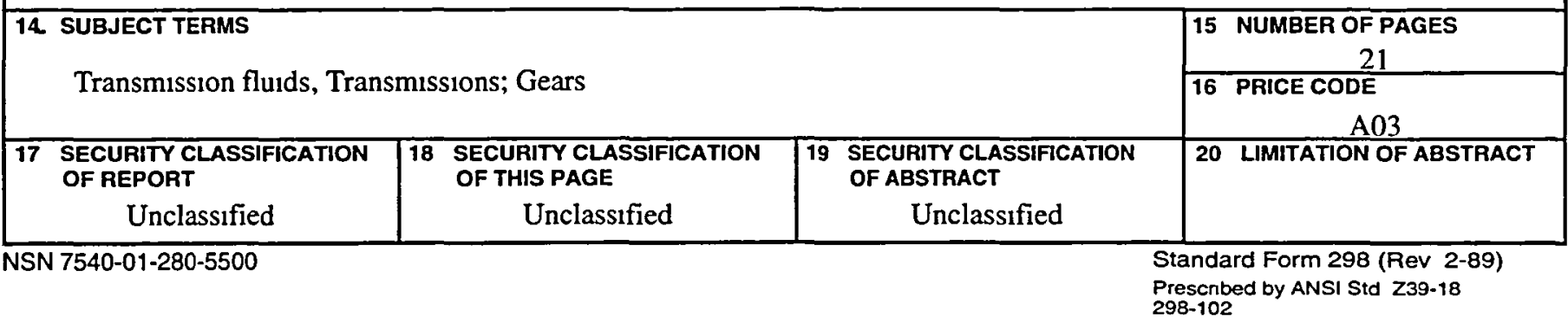




\section{End of Document}

